\title{
Plant development and nutrient uptake rate in Dendrobium nobile Lindl
}

Juliana Garcia dos Santos Ichinose, Cibele Mantovani, Renata Bachin Mazzini-Guedes, Kathia Fernandes Lopes Pivetta, Ricardo Tadeu de Faria, Roberto Lyra Villas Bôas \& Rodrigo Thibes Hoshino

To cite this article: Juliana Garcia dos Santos Ichinose, Cibele Mantovani, Renata Bachin MazziniGuedes, Kathia Fernandes Lopes Pivetta, Ricardo Tadeu de Faria, Roberto Lyra Villas Bôas \& Rodrigo Thibes Hoshino (2018) Plant development and nutrient uptake rate in Dendrobium nobile Lindl, Journal of Plant Nutrition, 41:15, 1937-1945, DOI: 10.1080/01904167.2018.1482913

To link to this article: https://doi.org/10.1080/01904167.2018.1482913

$$
\text { 电 Published online: } 05 \text { Sep } 2018 .
$$

Submit your article to this journal $־$

Џ Article views: 55

View Crossmark data ¿ 


\title{
Plant development and nutrient uptake rate in Dendrobium nobile Lindl
}

\author{
Juliana Garcia dos Santos Ichinose ${ }^{\mathrm{a}}$, Cibele Mantovani ${ }^{\mathrm{a}}$ (D), \\ Renata Bachin Mazzini-Guedes ${ }^{b}$, Kathia Fernandes Lopes Pivetta ${ }^{a}$, \\ Ricardo Tadeu de Faria ${ }^{c}$, Roberto Lyra Villas Bôas ${ }^{d}$, and Rodrigo Thibes Hoshino ${ }^{c}$ \\ ${ }^{a}$ School of Agricultural and Veterinarian Sciences (UNESP/FCAV), Path of Access Professor Paulo Donato

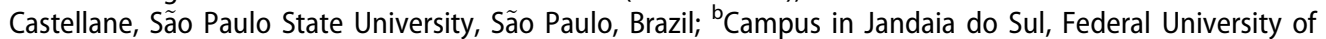 \\ Paraná (UFPR), Jandaia do Sul, Paraná, Brazil; 'State University of Londrina (UEL), Londrina, Paraná, Brazil; \\ ${ }^{\mathrm{d} S}$ Shool of Agriculture (UNESP/FCA), São Paulo State University, Botucatu, São Paulo, Brazil
}

\begin{abstract}
Dendrobium nobile Lindl. is one of the most cultivated and distributed orchids around the world; however, information on its nutrition is scarce. Our objective was to study the plant development and nutrient accumulation in plants of $D$. nobile weekly fertilized with $100 \mathrm{~mL}$ Sarruge nutrient solution at $75 \%$ concentration. One plant per replication was randomly collected every month, along 12 months, totaling four plants. Dry matter (DM) and nutrient accumulation were determined for the different plant parts. Plants had already accumulated nearly $50 \%$ of total DM up to the flowering stage (240 days after first fertilization, DAFF). Order and amount of accumulated nutrients, at 360 DAFF, was, in mg per plant: $\mathrm{K}(701.07)>\mathrm{N}(339.44)>\mathrm{Ca}$ (289.03) $>M g(135.44)>P(118.83)>S(23.56)$; in $\mu$ g per plant, it was $\mathrm{Fe}$ $(14,122.35)>\operatorname{Zn}(5,277.82)>\operatorname{Mn}(3,216.87)>B(1,253.02)>C u(271.25)$.
\end{abstract}

\section{ARTICLE HISTORY}

Received 10 May 2017

Accepted 27 March 2018

\section{KEYWORDS}

floriculture; orchidaceae; ornamental plants;

plant nutrition

\section{Introduction}

Orchids are highlighted as important ornamental and medicinal plants of great economic, ecological, and botanical interest. Orchid culture has progressed to a relevant activity as it now represents one of the most economically significant businesses in the global nursery industry (Silva 2013).

Production and sale of orchids as pot plants comprise an important segment in the sector; Brazil is an importer of seedlings coming, mainly, from the Netherlands, Thailand, and Japan. Imports totaled US\$10.739 million in 2013, and these plants are forwarded directly to commercial production (Junqueira and Peetz 2013).

Research on mineral nutrition of orchids is scarce. However, it is known that these plants have nutritional requirements similar to other species; the difference is that orchids usually take longer to show deficiency symptoms due to the slow growth (Naik et al. 2009). Furthermore, according to the literature, plants, in general, present diverse nutritional demands ranging with growth stages. However, most producers use conventional fertilizers available in the market, which are developed with the aim to attend crops of food production (Takane, Yanagisawa, and Pivetta 2010). This results in high cultivation costs and products of poor quality, what explains the importance of knowing the species nutrition requirements (Furtini, Boldrin, and Mattson 2015).

CONTACT Cibele Mantovani orquidariomantovani@gmail.com E School of Agricultural and Veterinarian Sciences (UNESP/ FCAV), Path of Access Professor Paulo Donato Castellane, São Paulo State University (Unesp), Via de Acesso Professor Paulo Donato Castellane, Jaboticabal 14884-900, São Paulo, Brazil.

Color versions of one or more of the figures in the article can be found online at www.tandfonline.com/lpla

(C) 2018 Taylor \& Francis Group, LLC 
The genus Dendrobium comprises around 900 species. Among them, Dendrobium nobile Lindl. stands out for being one of the most cultivated and distributed orchids in the world. It is appreciated for its color range and great number of flowers per plant (Nayak et al. 2002).

In the literature, there are some studies on Dendrobium nutrition, for instance, how rates of nitrogen, phosphorus, and potassium may influence growth and flowering of Dendrobium Red Emperor "Prince" (Bichsel, Starman, and Wang 2008), and how an interruption and reapplication of fertilization affects growth and flowering of D. nobile (Yen et al. 2008). However, these studies do not consider the rate of nutrient uptake in D. nobile.

From curves of nutrient uptake, it is possible to understand with great reliability the nutritional demand in each growth stage, so one can monitor the need of a certain nutrient along plant cycle for each phenological stage. The study of nutrient uptake rates in plants is important to quantify nutritional requirements and indicate most appropriate periods for fertilization (Pedrosa et al. 2000). Therefore, our objective was to study the dynamics of growth and nutrient accumulation in $D$. nobile cultivated under protection.

\section{Material and methods}

\section{Plant material and cultivation conditions}

The experiment was conducted under protection in a greenhouse coated by black nets with $50 \%$ shading on its sides and $70 \%$ shading on its top (average PPF of $300 \mu \mathrm{mol} \mathrm{m} \mathrm{m}^{-2} \mathrm{~s}^{-1}$ at noon), and maximum and minimum temperatures of 34 and $15^{\circ} \mathrm{C}$, respectively.

Seedlings of $D$. nobile were standardized regarding length of the biggest pseudobulb $(13-16 \mathrm{~cm})$, pseudobulb number $(2-3)$, and shoot number $(1-2)$. Plants were then transplanted and maintained along 2 months only with irrigation aiming at adaptation to the environment. Evaluations began 30 days after first fertilization (DAFF).

Black plastic pots $(11 \mathrm{~cm}$ height $\times 14 \mathrm{~cm}$ diameter $)$ were used for plant cultivation, which were filled with a layer of expanded clay on the bottom corresponding to $25 \%$ of pot volume, and with a 2:1 (v/v) mixture of pinus bark, and charcoal over it.

Fertilization was performed weekly with an application in each pot of $100 \mathrm{~mL}$ Sarruge complete nutrient solution at $75 \%$ concentration (Bernardi et al. 2004). Nutrient concentration in Sarruge solution, in $\mathrm{mg} \mathrm{L}^{-1}$, is: 225 nitrogen $(\mathrm{N})$; 31 phosphorus $(\mathrm{P}) ; 234$ potassium $(\mathrm{K}) ; 200$ calcium $(\mathrm{Ca})$; 48 magensium $(\mathrm{Mg}) ; 64$ sulfur $(\mathrm{S}) ; 0.5$ boron $(\mathrm{B}) ; 0.5$ manganese $(\mathrm{Mn}) ; 0.05$ zinc $(\mathrm{Zn}) ; 0.02$ copper $(\mathrm{Cu}) ; 0.01$ molybdenum (Mo); 5 iron (Fe); and 0.7 chloride $(\mathrm{Cl})$ (Sarruge 1975).

The $\mathrm{N}$ was provided in the form of nitrate and ammonium in equal proportions; and Fe-ethylenediaminetetraacetic acid was used as the source of Fe.

Irrigation was done manually by supply of $100 \mathrm{~mL}$ distilled water [pH 6.8 and electrical conductivity $(\mathrm{EC})=164.9 \mu \mathrm{S} \mathrm{cm}{ }^{-1}$ ] per pot three times a week.

\section{Nutrient uptake rate}

With the aim to comprise all plant development stages, treatments consisted of plant collection every 30 days along 12 months. Each sample was composed of four plants, so each plant was considered one replication. Morphometric characteristics of leaves, pseudobulbs, roots, and inflorescences were then determined.

The following characteristics were measured monthly to evaluate plant development: leaf area $\left(\mathrm{dm}^{2}\right)$, with the help of an electronic leaf area meter (Li-Cor, Lincoln, NE; model L1-3100 ${ }^{\circledR}$ ); leaf number; pseudobulb number; pseudobulb diameter $(\mathrm{mm})$, with a digital caliper rule (Digimess ${ }^{\circledR}$, amplitude of $0.01-300 \mathrm{~mm})$; pseudobulb length $(\mathrm{cm})$, with a ruler; shoot number; and dry matter $(\mathrm{DM})$ of leaves, pseudobulbs, roots, inflorescences, and the entire plant (g). After washed, the 
plant material was dried in a forced air circulation heater at $70^{\circ} \mathrm{C}$ until reaching constant weight on a digital scale $(0.01 \mathrm{~g}$ precision) for determination of DM.

After DM was measured, the plant material was ground for determination of macro $(\mathrm{N}, \mathrm{P}, \mathrm{K}$, $\mathrm{Ca}, \mathrm{Mg}$, and $\mathrm{S}$ ) and micronutrient $(\mathrm{B}, \mathrm{Cu}, \mathrm{Fe}, \mathrm{Mn}$, and $\mathrm{Zn}$ ) concentration in the different plant parts (leaves, pseudobulbs, roots, and inflorescences) according to Malavolta, Vitti, and Oliveira (1997). From nutrient contents, nutrient accumulation was calculated via multiplication of contents by DM values to obtain the nutrient uptake rate.

Monitoring of $\mathrm{pH}$ and EC was performed from the pour throw. Therefore, at collection time, plants were maintained at maximum water retention capacity of the substrate using distilled water at $\mathrm{pH}$ 7.0. After $2 \mathrm{hr}, 50 \mathrm{~mL}$ water was added in each pot so the pour throw could be collected for later measurement of $\mathrm{pH}$ and EC (Kämpf 2005).

\section{Statistical analysis}

Data of DM from the different plant parts, pseudobulb length, number, and diameter, shoot number, leaf area and number, were submitted to polynomial regression with the aim to verify plant behavior along one-year cycle. From results of DM and nutrient concentration, curves of nutrient accumulation were obtained.

Data of $\mathrm{pH}$ and EC were submitted to variance analysis, and means were compared by the Tukey test at $5 \%$ probability.

\section{Results and discussion}

\section{Plant growth and development}

Along the experimental period, there was a gradual increase in pseudobulb number, length, and diameter. Maximum mean values were reached at $360 \mathrm{DAFF}$, so greatest pseudobulb length was $28.9 \mathrm{~cm}$, largest diameter was $1.45 \mathrm{~cm}$ and average number was three (Figure 1). At 300 DAFF, we observed the highest mean number of shoots, that is, 1.95 (Figure 1). Mean leaf area, at cycle end, was $708.68 \mathrm{dm}^{2}$, while maximum leaf number was 7.9 (Figure 1).

Along the 360-day evaluation period, there was an increase in total plant DM with a differentiated matter increment from 240 DAFF; besides the linear gain observed for roots and leaves, there was also a rise in pseudobulb matter (Figure 2). From total plant DM, 47.13\% came from pseudobulbs, $20.36 \%$ from roots, and $32.52 \%$ from leaves.

At 240 DAFF, plants had developed flower stems, therefore it was the beginning of the flowering stage; at this time, plants already had more than 50\% of total DM. Up to 120 DAFF, in general, increase in total DM had greater contribution from pseudobulbs; from 120 to 240 DAFF, increment in total DM was due, mainly, to accumulation of DM in leaves and roots. However, after 240 DAFF, all plant parts added to the accumulation of total DM (Figure 2).

This was expected, once Dendrobium plant development is sympodial with apical dominance, so pseudobulbs grow up to a certain size, followed by shoot development that contributes to the emergence of new leaves. Growth of new pseudobulbs is then assisted by the oldest pseudobulb. Therefore, youngest pseudobulbs grow and accumulate more matter than previous ones, resuming the increase in plant height.

\section{Nutrient accumulation}

Regarding the total of nutrients accumulated by plants at 360 DAFF, greatest macronutrient accumulation was found in pseudobulbs (Figure 3). 

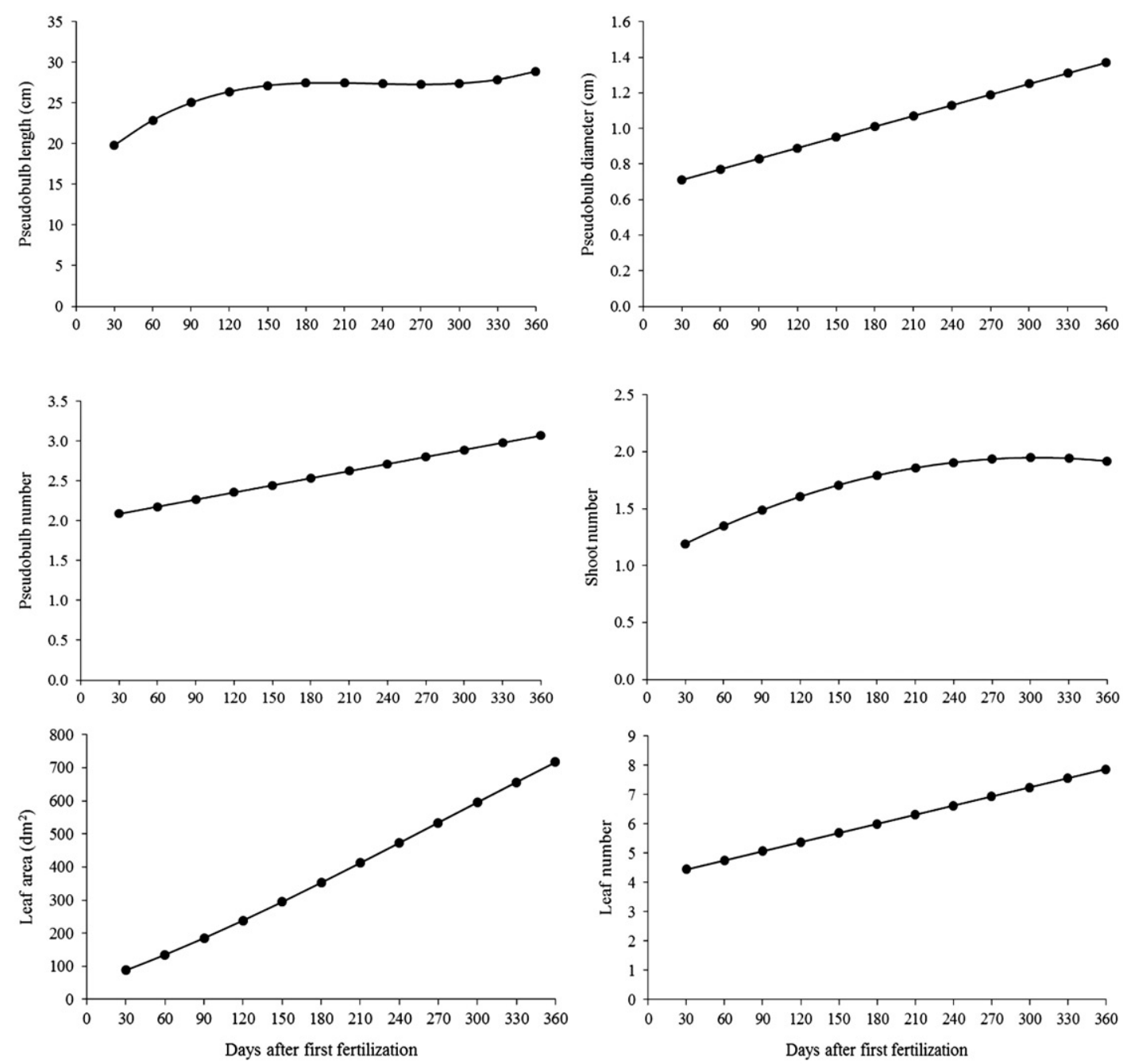

Figure 1. Pseudobulb length, diameter, and number; shoot number; and leaf area and number of $D$. nobile plants cultivated under protection according to DAFF (2 months after seedling transplant).

Macronutrient accumulation in D. nobile plants occurred at the daily rate of, in $\mathrm{mg}$ plant $^{-1}$ : $0.94 \mathrm{~N}, 0.33 \mathrm{P}, 1.95 \mathrm{~K}, 0.80 \mathrm{Ca}, 0.38 \mathrm{Mg}$, and $0.07 \mathrm{~S}$ (Figure 3). Sulfur was the macronutrient that presented the lowest rate from the first fertilization up to $360 \mathrm{DAFF}$.

Regarding the total of nutrients accumulated by plants at 360 DAFF (Table 1), the greatest macronutrient accumulation was found in the pseudobulbs.

Considering the general balance among nutrients, leaves and pseudobulbs presented equivalent relationships, where total $\mathrm{N}: \mathrm{P}: \mathrm{K}$ ratio was 2.8:1.0:5.9, which is similar to 3.1:1.0:6.6 and 2.8:1.0:6.7 found for leaves and pseudobulbs, respectively. However, roots showed the N:P:K ratio of 2.6:1.0:2.4. Therefore, for development of both leaves and pseudobulbs, the N:P:K ratio close to 3.0:1.0:6.0 may be used, as it is considered appropriate according to total accumulation of $\mathrm{N}, \mathrm{P}$, and $\mathrm{K}$ (Table 1).

Poole and Sheehan (1982) report that Cattleya, Phalaenopsis, and Cymbidium orchids have different requirements, so best N:P:K ratios for these genus are: 2.5:1.0:2.0 for Cattleya and Cymbidium, and 1.25:1.0:1.9 for Phalaenopsis. However, for Cymbidium sinense, the N:P:K ratio in plant tissues is 6.0:1.0:9.0; $\mathrm{K}$ application, particularly, increased soluble sugars, starch, cellulose, and proteins (Pan, Ye, and Hew 1997). 


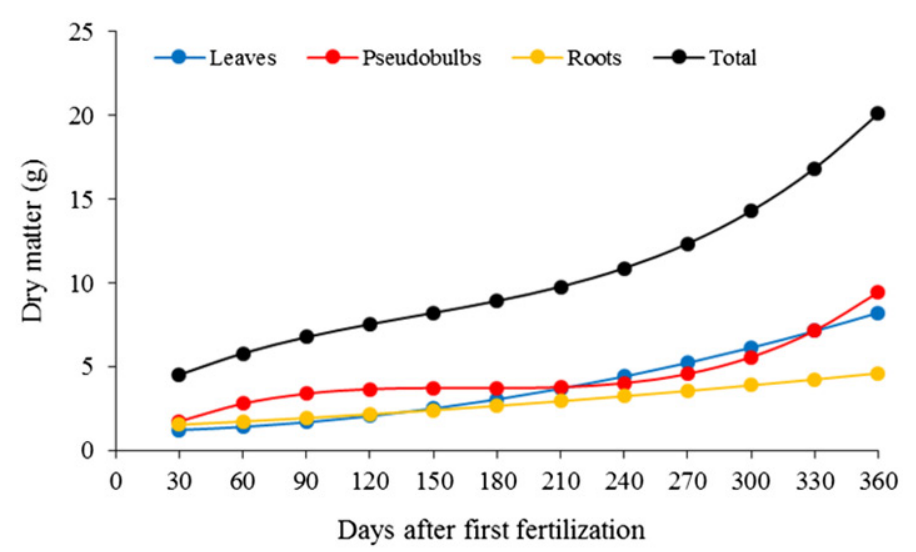

Figure 2. DM of pseudobulbs, leaves, roots, and total DM of D. nobile plants cultivated under protection according to DAFF (2 months after seedling transplant).

In general, solutions with similar concentrations of $\mathrm{N}$ and $\mathrm{K}$ are indicated for Dendrobium. Bichsel, Starman, and Wang (2008) report that fertilization with $100 \mathrm{mg} \mathrm{L}^{-1} \mathrm{~N}, 25 \mathrm{mg} \mathrm{L}^{-1} \mathrm{P}$, and $100 \mathrm{mg} \mathrm{L}^{-1} \mathrm{~K}$ is appropriate for both vegetative and reproductive stages. However, higher $\mathrm{K}$ concentrations are used for Phalaenopsis, so Wang (2007) indicates fertilization with $300 \mathrm{mg} \mathrm{L}^{-1} \mathrm{~K}$ combined with $200 \mathrm{mg} \mathrm{L}^{-1} \mathrm{~N}$ and $\mathrm{P}$ for plant growth and flowering. Regarding $\mathrm{P}$, studies denote that it is the most limiting nutrient for epiphytes, as these plants are adapted to use such nutrient efficiently; in nature, N:P ratios ranging from 16:1 to 14:1 are common, but when plants are cultivated, such ratio is expressively reduced (Zotz 2004).

For Ca:Mg ratios, leaves had a higher relationship-2.8:1.0, than pseudobulbs-2.0:1.0, while roots showed the ratio 1.6:1.0. These results indicate that $\mathrm{Ca}$ is more required in leaves than $\mathrm{Mg}$. However, for fertilization with $\mathrm{Ca}$ and $\mathrm{Mg}$, the ratio 2.0:1.0 (in relation to concentration) is appropriate since the relationship for the entire plant was 2.1:1.0 (Table 1).

In fact, these results also indicate that, for D. nobile, $\mathrm{Mg}$ is important; such $\mathrm{Ca}: \mathrm{Mg}$ ratio (2.0:1.0) may be considered low, once in nutrient solutions such as Sarruge or Hoagland, supply of $\mathrm{Ca}$ is four times greater than of $\mathrm{Mg}$ (Sarruge 1975; Hoagland and Arnon 1950). Poole and Seehan (1977) highlight the importance of $\mathrm{Mg}$ on studies of Cymbidium, Phalaenopsis, and Cattleya nutrition; the authors mention that, for daily fertigations, nutrient solutions must comprise $100 \mathrm{mg} \mathrm{L}^{-1} \mathrm{~N}, 50-100 \mathrm{mg} \mathrm{L}^{-1} \mathrm{~K}$, and $25 \mathrm{mg} \mathrm{L}^{-1} \mathrm{Mg}$ for Cymbidium and Phalaenopsis, but for Cattleya, only $50 \mathrm{mg} \mathrm{L}^{-1} \mathrm{~N}, \mathrm{~K}$, and $\mathrm{Mg}$ are required.

For macronutrients, greatest sink parts were pseudobulbs, with a mean of $52.1 \%$ of the total accumulated, followed by leaves (31.7\%) and roots (16.2\%). These results suggest that the pseudobulbs acted as nutrient reserves, so such accumulation was expected once there was more DM also in such plant part (Table 1). According to Ng and Hew (2000), pseudobulbs play an essential role on orchid growth and survival, accumulating water, mineral nutrients, and carbohydrates that assist on shoot emission and flowering. In addition, for Dendrobium orchids, Wang (1995) reports that the pseudobulb development and growth implies in greater flower number in the following year.

Regarding micronutrient accumulation in the different plant parts, and based on the last plant collection at $360 \mathrm{DAFF}$, daily uptake rates were, in $\mu \mathrm{g}$ plant $^{-1}: 3.48 \mathrm{~B}, 8.94 \mathrm{Mn}$, and $14.66 \mathrm{Zn}$ (Figure 4). The most accumulated micronutrient was $\mathrm{Fe}$, with the daily rate of $39.23 \mu \mathrm{g} \mathrm{plant}^{-1}$, while $\mathrm{Cu}$ was the least accumulated at the daily rate of $0.75 \mu \mathrm{g}$ plant $^{-1}$.

At final evaluation, there was greater accumulation of macronutrients and $\mathrm{Zn}$ in the pseudobulbs, while highest $\mathrm{Cu}$ accumulation was found in the roots. For the other micronutrients, leaves were the main sink (Table 1). In general, micronutrients act as enzymatic activators, so $\mathrm{Fe}$ and 

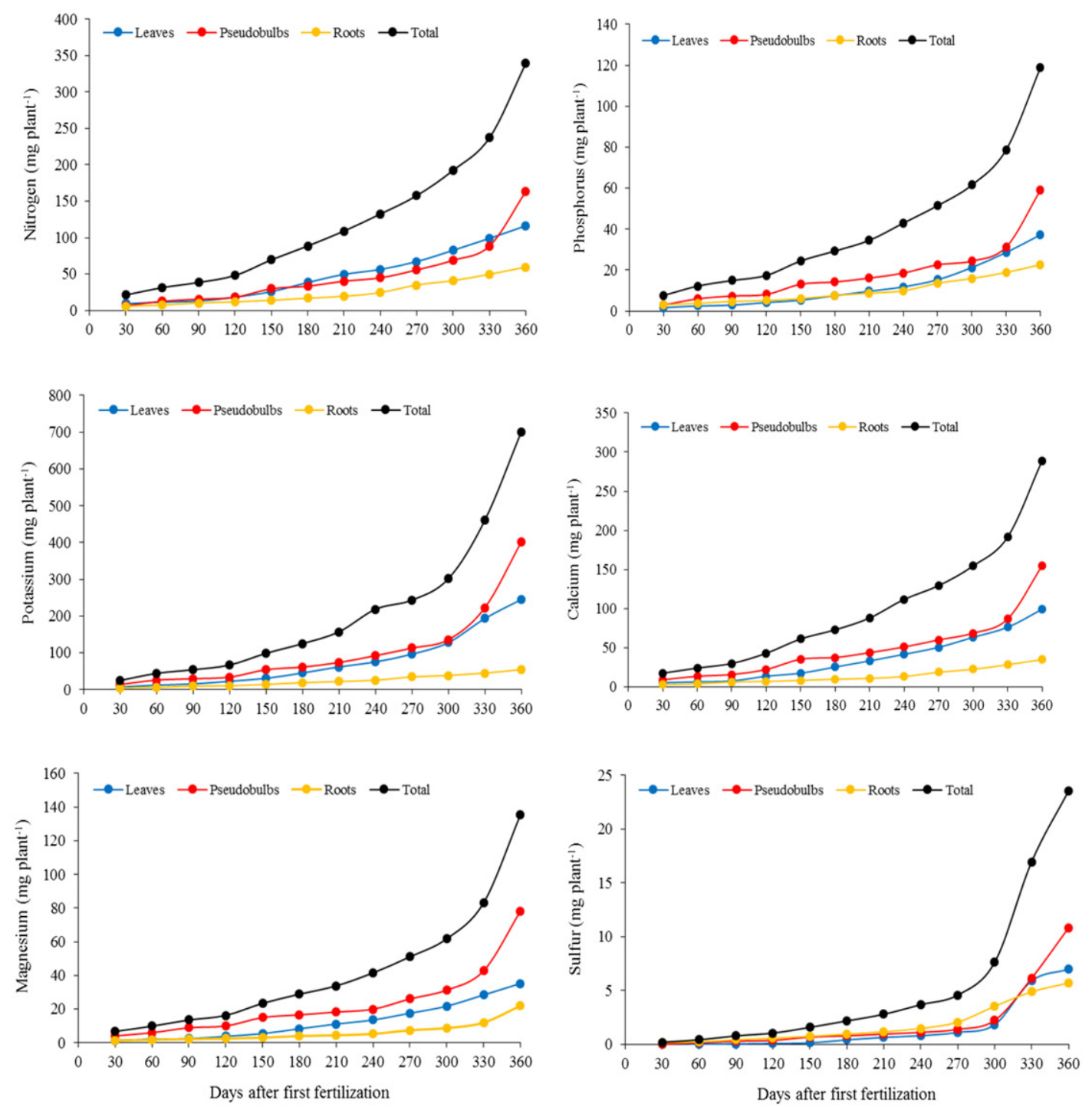

Figure 3. Macronutrient accumulation-nitrogen, phosphorus, potassium, calcium, magnesium, and sulfur, in leaves, pseudobulbs, roots, and total accumulation in D. nobile plants cultivated under protection according to DAFF ( 2 months after seedling transplant).

$\mathrm{Mn}$ are related to photosynthesis and participate in electron transference and water photolysis (Malavolta 2006). Therefore, higher micronutrient accumulation in leaves was already expected.

Comparing nutrient concentrations in Cattleya and Laelia orchids with other cultivated plants, Carlucci, Haag, and Bellote (1980) report that, in these orchid species, concentrations of B, $\mathrm{Cu}$, $\mathrm{Fe}, \mathrm{Mn}$, and $\mathrm{Zn}$ were significantly higher than macronutrient concentration; but we found higher concentrations of macronutrients than micronutrients for $D$. nobile.

Flowering occurred at $240 \mathrm{DAFF}$. There was an average of two flowers per stem, totaling 11 flowers per plant. DM and accumulated nutrients are shown in Table 2. Following the descending order, most accumulated macronutrients were $\mathrm{K}, \mathrm{Ca}, \mathrm{N}, \mathrm{S}, \mathrm{Mg}$, and $\mathrm{P}$ and most accumulated micronutrients were $\mathrm{Fe}, \mathrm{Mn}, \mathrm{B}, \mathrm{Zn}$, and $\mathrm{Cu}$.

The high $\mathrm{K}$ amount found in flowers (and in the entire plant) suggests that plants have a great demand for such nutrient during the flowering period. 
Table 1. Nutrient accumulation in leaves, pseudobulbs, roots, and total accumulated amount in $D$. nobile plants cultivated under protection at 360 DAFF (2 months after seedling transplant).

\begin{tabular}{|c|c|c|c|c|}
\hline Nutrient & Leaves & Pseudobulbs & Roots & Total accumulated \\
\hline \multicolumn{5}{|c|}{$\mathrm{mg} \mathrm{plant}^{-1}$} \\
\hline N & 116.40 (34\%) & $163.35(48 \%)$ & $59.68(18 \%)$ & 339.44 \\
\hline$P$ & $37.18(31 \%)$ & $58.99(50 \%)$ & $22.66(19 \%)$ & 118.83 \\
\hline K & 244.87 (35\%) & $401.80(57 \%)$ & $54.40(8 \%)$ & 701.07 \\
\hline $\mathrm{Ca}$ & 99.19 (34\%) & $154.96(54 \%)$ & $34.88(12 \%)$ & 289.03 \\
\hline $\mathrm{Mg}$ & $35.21(26 \%)$ & 78.19 (58\%) & 22.04 (16\%) & 135.44 \\
\hline$S$ & $6.99(29 \%)$ & $10.85(46 \%)$ & $5.72(25 \%)$ & 23.56 \\
\hline Nutrient & Leaves & Pseudobulbs & Roots & Total accumulated \\
\hline \multicolumn{5}{|c|}{$\mu \mathrm{g}$ plant $^{-1}$} \\
\hline B & $502.92(40 \%)$ & 435.07 (35\%) & $315.03(25 \%)$ & $1,253.02$ \\
\hline $\mathrm{Cu}$ & 85.17 (31\%) & $66.60(25 \%)$ & $119.48(44 \%)$ & 271.25 \\
\hline $\mathrm{Fe}$ & $6,208.65(44 \%)$ & $4,248.14(30 \%)$ & $3,665.56(26 \%)$ & $14,122.35$ \\
\hline $\mathrm{Mn}$ & $1,652.18(52 \%)$ & $1,360.82(42 \%)$ & $203.87(6 \%)$ & $3,216.87$ \\
\hline $\mathrm{Zn}$ & $1,689.94(32 \%)$ & $2,505.87(48 \%)$ & $1,082.01(20 \%)$ & $5,277.82$ \\
\hline
\end{tabular}
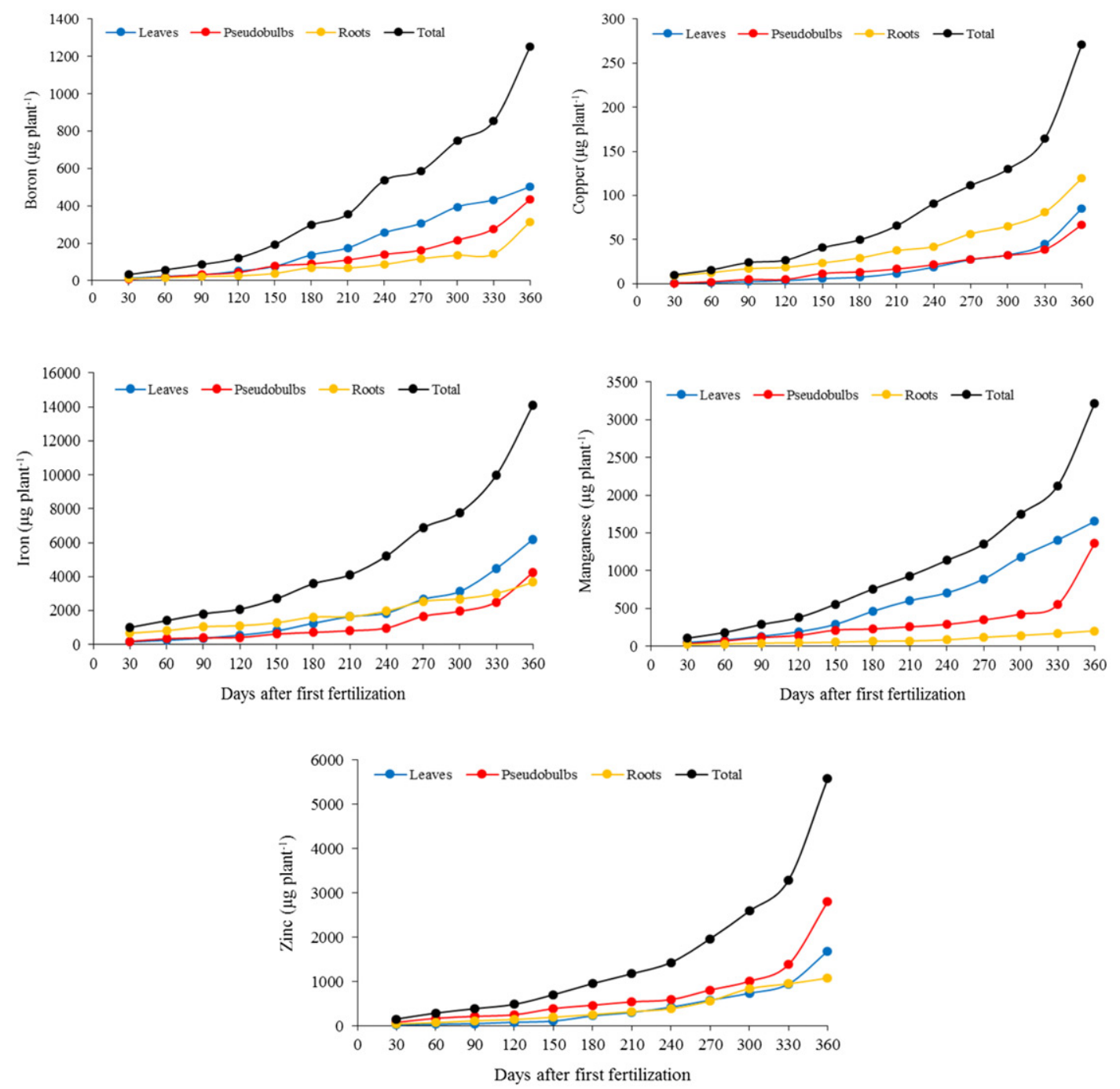

Figure 4. Micronutrient accumulation-boron, copper, iron, manganese, and zinc, in leaves, pseudobulbs, roots, and total accumulation in D. nobile plants cultivated under protection according to DAFF ( 2 months after seedling transplant). 
Table 2. Macronutrients, micronutrients, and DM of flowers of D. nobile cultivated under protection at 240 DAFF (2 months after seedling transplant).

\begin{tabular}{|c|c|c|c|c|c|}
\hline $\mathrm{N}$ & $\mathrm{P}$ & K & $\mathrm{Ca}$ & $\mathrm{Mg}$ & $S$ \\
\hline \multicolumn{6}{|c|}{$\mathrm{mg} \mathrm{plant}^{-1}$} \\
\hline 6.60 & 2.70 & 25.49 & 6.76 & 2.76 & 2.89 \\
\hline $\mathrm{DM}$ & B & $\mathrm{Cu}$ & $\mathrm{Fe}$ & $\mathrm{Mn}$ & $\mathrm{Zn}$ \\
\hline g & & & $\mu \mathrm{g}$ plant $^{-1}$ & & \\
\hline 0.85 & 52.82 & 8.76 & 431.00 & 58.88 & 20.74 \\
\hline
\end{tabular}

Table 3. Means of $\mathrm{pH}$ and $\mathrm{EC}$ of the pour throw collected from the substrate of $D$. nobile pots according to DAFF (2 months after seedling transplant).

\begin{tabular}{llc}
\hline DAFF & \multicolumn{1}{c}{$\mathrm{pH}$} & EC $\left(\mu \mathrm{S} \mathrm{cm}^{-1}\right)$ \\
\hline 30 & $5.13^{\mathrm{a}, \mathrm{b} . \mathrm{c}}$ & $190.6^{\mathrm{b}, \mathrm{c}, \mathrm{d}}$ \\
60 & $5.59^{\mathrm{a}}$ & $178.3^{\mathrm{d}, \mathrm{e}}$ \\
90 & $5.49^{\mathrm{a}}$ & $205.1^{\mathrm{a}, \mathrm{b}, \mathrm{c}}$ \\
120 & $4.76^{\mathrm{a}, \mathrm{b}, \mathrm{c}, \mathrm{d}}$ & $180.0^{\mathrm{d}, \mathrm{e}}$ \\
150 & $5.19^{\mathrm{a}, \mathrm{b}}$ & $134.0^{\mathrm{g}}$ \\
180 & $4.48^{\mathrm{b}, \mathrm{c}, \mathrm{d}, \mathrm{e}}$ & $162.3^{\mathrm{e}, \mathrm{f}}$ \\
210 & $4.22^{\mathrm{c}, \mathrm{d}, \mathrm{e}}$ & $156.5^{\mathrm{f}}$ \\
240 & $3.90^{\mathrm{d}, \mathrm{e}}$ & $156.3^{\mathrm{f}}$ \\
270 & $3.97^{\mathrm{d}, \mathrm{e}}$ & $186.8^{\mathrm{c}, \mathrm{d}}$ \\
300 & $3.73^{\mathrm{e}}$ & $193.1^{\mathrm{b}, \mathrm{c}, \mathrm{d}}$ \\
330 & $4.02^{\mathrm{d}, \mathrm{e}}$ & $210.0^{\mathrm{a}, \mathrm{b}}$ \\
360 & $3.99^{\mathrm{d}, \mathrm{e}}$ & $225.3^{\mathrm{a}}$ \\
MSD & 0.96 & 20.87 \\
CV (\%) & 8.60 & 4.66 \\
\hline
\end{tabular}

Minimum significant difference.

Numbers followed by same superscript letters in the column do not differ from each other by the Tukey test at $5 \%$ probability.

Macronutrient accumulation in D. nobile flowers was slightly superior to that reported by Carlucci, Haag, and Bellote (1980) for three species of Laelia and two of Cattleya. The same occurred for micronutrients, with the exception of $\mathrm{Mn}$ and $\mathrm{Zn}$.

\section{pH and EC}

Initially, the substrate was alkalized due, mainly, to bases in the nutrient solution, such as $\mathrm{Ca}$ and $\mathrm{Mg}$ adsorbed on the substrate, rising the $\mathrm{pH}$ (Table 3). From plant growth and development, $\mathrm{pH}$ is usually reduced due to $\mathrm{H}^{+}$release because of root ionic absorption (Taiz and Zaiger 2009). These results were similar to those described by Yen et al. (2008), who states that $\mathrm{pH}$ decrease occurs especially by root activity.

Besides substrate acidification, there were no negative consequences in plant development, so the $\mathrm{pH}$ range of $4.8-6.2$ is indicated for orchid development (Takane, Yanagisawa, and Pivetta 2010); according to the authors, $500 \mu \mathrm{S} \mathrm{cm}^{-1} \mathrm{EC}$ is the tolerated by orchids, which is twice the maximum value found in this work.

\section{Conclusions}

At 360 DAFF, which occurred 2 months after seedling transplant, macronutrient uptake by $D$. nobile plants, following the descending order, was: $\mathrm{K}>\mathrm{N}>\mathrm{Ca}>\mathrm{Mg}>\mathrm{P}>\mathrm{S}$; for micronutrients, it was: $\mathrm{Fe}>\mathrm{Zn}>\mathrm{Mn}>\mathrm{B}>\mathrm{Cu}$. During the flowering period, D. nobile has a high demand for potassium. The period of greatest nutrient requirement was after flowering, that is, from 241 to 360 DAFF. Reduction in $\mathrm{pH}$ and increase in EC did not influence plant development. 


\section{ORCID}

Cibele Mantovani (iD http://orcid.org/0000-0002-4081-9278

\section{References}

Bernardi, A. C., R. T. Faria, J. F. R. P. Carvalho, L. K. Unemoto, and A. M. de Assis. 2004. Plant growth of Dendrobium nobile lindl. fertigated with different concentrations of the nutrient solution sarruge. Vol. 25, 13-20. Semina: Ciências Agrárias.

Bichsel, R. G., T. W. Starman, and Y. T. Wang. 2008. Nitrogen, phosphorus, and potassium requirements for optimizing growth and flowering of the dendrobium nobile as a potted orchid. HortScience 43:328-332.

Carlucci, M. V., H. P. Haag, and A. F. J. Bellote. 1980. Mineral nutrition of ornamental plants. IX. In Chemical composition and nutrient extraction by five species of Orchidaceae, ed. H. P. Haag, K. Minami and A. M. L. P. Lima, 27-34. Campinas: Fundação Cargill.

Furtini, N. A. E., K. V. F. Boldrin, and N. S. Mattson. 2015. Nutrition and quality in ornamental plants. Ornamental Horticulture 21 (2):139-150.

Hoagland, D. R., and D. I. Arnon. 1950. The water-culture method for growing plants without soil. Circular, 347 , 2nd ed. California: Agricultural Experiment Station.

Junqueira, A. H., and M. S. Peetz. 2013. Balance of the foreign trade of the Brazilian Floriculture. Hórtica, 2014. http://www.hortica.com.br/artigos/2014/2013_Comercio_Exterior_Floricultura.pdf. (accessed July 11, 2018).

Kämpf, A. N. 2005. Commercial production of ornamental plants, 2. Guaíba: Agrolivros.

Malavolta, E. 2006. Manual of mineral nutrition of plants, 638. São Paulo: Agronômica Ceres.

Malavolta, E., G. C. Vitti, and S. A. Oliveira. 1997. Evaluation of the nutritional status of plants: principles and applications, 319. Piracicaba: Potafos.

Naik, S. K., T. U. Bharathi, D. Barman, R. Devadas, and R. P. Medhi. 2009. Status of mineral nutrition of orchid-a review. Journal of Ornamental Horticulture 12:1-14.

Nayak, N. R., S. Sahoo, S. Patnaik, and S. P. Rath. 2002. Establishment of thin cross section (TCS) culture method for rapid micropropagation of Cymbidium aloifolium (L.) sw. and Dendrobium nobile lindl. (orchidaceae). Scientia Horticulturae 94 (1-2):107-116.

Ng, C. K. Y., and C. S. Hew. 2000. Orchid pseudobulbs-false'bulbs with a genuine importance in orchid growth and survival. Scientia Horticulturae 83:165-172.

Pan, R. C., Q. S. Ye, and C. S. Hew. 1997. Physiology of Cymbidium sinense: A review. Scientia Horticulturae 70:123-129.

Pedrosa, M. W., J. Geraldo Barbosa, H. Prieto Martínez, and A. Américo Cardoso. 2000. Concentration and accumulation of nutrients in plants of Gypsophila paniculata L. grown in nutrient solution. Revista Brasileira De Horticultura Ornamental 6 (1):49-56.

Poole, H. A., and T. J. Sheehan. 1977. Effects of media and supplementary micro element fertilization and growth and chemical composition of cattleya. American Orchid Society Bulletin 46:153-160.

Poole, H. A., and T. J. Sheehan. 1982. Mineral nutrition of orchid roots. In Orchid biology: Reviews and perspectives, ed. J. Arditti, vol. II, 195-212. Ithaca, NY: Cornell University Press.

Sarruge, J. R. 1975. Nutrition solutions. Summa Phytopathologica 1:231-233.

Silva, J. T. 2013. Orchids: Advances in tissue culture, genetics, phytochemistry and transgenic biotechnology. Floriculture Ornamental Biotechnology 7:1-52.

Taiz, L., and E. Zeiger. 2009. Plant physiology, 4th ed, 819. Porto Alegre: Artmed.

Takane, R. J., S. S. Yanagisawa, and K. F. L. Pivetta. 2010. Modern cultivation of Cattleya orchids and its hybrids, 179. Fortaleza: Graf House.

Wang, Y. T. 1995. Medium and fertilization affect performance of potted dendrobium and phalaenopsis. HortTecnology 5 (3):234-237.

Wang, Y. T. 2007. Potassium nutrition affects phalaenopsis growth and flowering. HortScience 42 (7):1563-1567.

Yen, C. Y. T., T. W. Starman, Y. T. Wang, A. Holzenburg, and G. Niu. 2008. Timing of nutrient termination and reapplication for growth, flower initiation, and flowering of the Dendrobium nobile orchid. Journal of the American Society for Horticultural Science 133:501-507.

Zotz, G. 2004. The reabsorption of phosphorus is greater than that of nitrogen in senescing leaves of vascular epiphytes from lowland Panama. Journal of Tropical Ecology 20 (06):693-696. 